\title{
SLE during pregnancy, maternal and perinatal outcome in teritary hospital
}

\author{
Leelavathi, Nayana D. H.*, Triveni Kondareddy, Kaytri S.
}

Department of Obstetrics and Gynecology, JSS medical college and hospital, Mysore, Karnataka, India

Received: 18 November 2016

Accepted: 13 December 2016

\section{*Correspondence:}

Dr. Nayana D. H.,

E-mail: dh.nayana@gmail.com

Copyright: ( $)$ the author(s), publisher and licensee Medip Academy. This is an open-access article distributed under the terms of the Creative Commons Attribution Non-Commercial License, which permits unrestricted non-commercial use, distribution, and reproduction in any medium, provided the original work is properly cited.

\section{ABSTRACT}

Background: SLE is an autoimmune disease most frequently found in women of child bearing age and may co-exist with pregnancy. Its multisystem involvement and therapeutic interventions pose a high risk for both the mother and the foetus. Disease flares in pregnancy pose challenges with respect to distinguishing physiologic changes related to pregnancy from disease related manifestations. The present study analyzes the fetomaternal outcome of pregnant women with SLE.

Methods: An analysis of fetomaternal outcome of pregnant women with SLE during April 2015 to May 2016 at JSS hospital.

Results: During the period from April 2016 to May 2016, 3773 deliveries were conducted in the department. Eleven pregnant women with SLE were followed up during this period, giving an incidence of 0.29/1000 deliveries. A high rate of lupus flare during pregnancy was found in the current study. Even among women in remission for more than six months before pregnancy, the rate of lupus flare was not low (27\%). Also other complications seen were preeclampsia $54.54 \%$, HELLP syndrome in $9.09 \%$, PPH in 50\%, polyserositis seen in $9.09 \%$ and one maternal death was seen $(9.09 \%)$. No neonate suffered from heart-blocker however there was $75 \%$ NICU admissions among live borns.

Conclusions: Advancing technology and better understanding of the maternal-foetal relationship in lupus have improved outcomes in lupus pregnancies over the last decade. The multisystem nature of the disease, the severity of the organ involvement needs to be assessed and a multidisciplinary approach is required for its diagnosis and successful management.

Keywords: Maternal outcome, Perinatal outcome, Pregnancy, SLE

\section{INTRODUCTION}

Systemic lupus erythematosus (SLE) is a common autoimmune disease and predominantly affects fertile women. The usual disease onset is in the third to fourth decades of life, in the reproductive years. ${ }^{1,2}$

Some previous studies indicated that pregnant women with SLE are at a higher risk of adverse pregnancy outcomes. $^{3-5}$ The other important concern is the impact of pregnancy on SLE. Aberrations in pregnancy-related maternal immune adaptations are likely contributors for this. However, there has been a trend towards more favourable outcomes.

Pregnancy and its outcome is a major concern to most SLE patients. SLE may also be associated with secondary APS (anti-phospholipid syndrome) which is a multisystem disorder characterized by recurrent abortions and also other systemic manifestations. ${ }^{6}$ They are at higher risk for exacerbations of the disease during pregnancy like spontaneous abortions, intrauterine foetal 
death, pre-eclampsia and eclampsia, preterm delivery and intrauterine growth restriction. Also queries regarding the safety of various drugs used are often raised. The diagnostic criteria of SLE, if first suspected during pregnancy are not different from those of non-pregnant women. $^{7}$

The prognosis for both mother and child is best when SLE has been quiescent for at least six months prior to the pregnancy. ${ }^{8}$ Disease flares during SLE pregnancy pose challenges with respect to distinguishing physiologic changes related to pregnancy from diseaserelated manifestations. ${ }^{9}$ Thus, a multidisciplinary approach with close medical, obstetric, and neonatal monitoring is necessary to optimize both maternal and fetal outcomes.

As we know, there is a paucity of data on pregnancy of Indian women with SLE. The aim of this study was to evaluate the maternal and fetal outcomes of pregnant women with SLE. The present study analyzes the fetomaternal outcome of pregnant women with SLE.

\section{METHODS}

Study was done at JSS Medical College and Hospital, Mysore. An analysis of feto-maternal outcome of pregnant women with SLE was done during April 2015 to May 2016. Pregnancy associated with SLE, diagnosed/referred during antenatal check-up at JSS Hospital, Mysore were source of data.

\section{Inclusion criteria}

We conducted a prospective study in order to determine planned pregnancy outcome in systemic lupus erythematosus followed in a tertiary referral centre. Once patient presented with known case of SLE/diagnosed first time with pregnancy councelling done regarding the disease (SLE) its course during pregnancy and delivery and its complication in detail, written consent taken with respect to counseling as well as for study.

Assessment of SLE: A detailed history was taken and general, systemic and obstetric examinations were carried out.

\section{Obstetrician visits are as follows:}

- Monthly until 20 weeks,

- every two weeks until 28 weeks,

- weekly after 28 weeks until delivery.

\section{Rheumatologist visits were every 4-6 weeks.}

First visit investigations included complete blood count (CBC) with platelets, renal function tests, liver function tests, urinalysis, 24 hour urine protein excretion ,anti-dsDNA antibody, anti-cardiolipin, lupus anticoagulant, anti-
Ro,/SSA antibody, anti-La/SSB antibody, thrombophilia profile were carried out.

During each antenatal visits $\mathrm{CBC}$ and platelets, blood glucose, BUN, creatinine, uric acid, AST, and ALT, urinalysis, coagulation profile were carried out. 24-hour proteinuria or protein/creatinine ratio was done if preeclampsia or lupus nephritis was suspected.

Foetal monitoring included: a) monthly ultrasound and doppler velocimetry studies after 24 weeks: for evaluation of fetal growth, amniotic fluid, and umbilical artery (fetal-placental flow), b) uterine artery evaluation at 24 weeks: screening tests for preeclampsia and intrauterine growth restriction c) fetal ECHO at 24 and 30 weeks d) CTG was performed on a weekly basis after 32 weeks.

Intervals of the visits and frequency of laboratory tests may be frequent in case of progress in disease activity or suspected complications like preeclampsia, flares etc. During each visit we looked for signs and symptoms of organ damage, dermatological changes, musculoskeletal damage, hematological changes, kidney and nervous system. All drugs administered pre-conception, during pregnancy and puerperium were recorded.

\section{Outcome measures}

The maternal outcome was noted in terms of the mode of termination of pregnancy, maternal complications and maternal end result till 1 montth post natally.

Fetal outcome was assessed by perinatal morbidity and mortality, need for admission in NICU, and neonatal end result till 1 month post natally.

\section{RESULTS}

During the period from April 2016 to May 2016, 3773 deliveries were conducted in the department. Eleven pregnant women with SLE were followed up during this period, giving an incidence of $0.29 / 1000$ deliveries. $72 \%$ (8/11) were between 20 and 30 years of age and $27 \%(3 / 11)$ were between 30 and 40 years of age. Among 11 patients $63 \%(7 / 11)$ had remission for $>6$ months before pregnancy, 27\% (3/11) patients had SLE disease activity in the six months before pregnancy and $9 \%$ (1/11) had new onset SLE during pregnancy.

Table 1: Pregnancy outcome.

\begin{tabular}{|l|l|l|}
\hline Outcome & Number $(\mathbf{n = 1 1})$ & $\begin{array}{l}\text { Percentag } \\
\text { e }\end{array}$ \\
\hline $\begin{array}{c}\text { Mode of delivery } \\
\text { Vaginal }\end{array}$ & 8 & $72.72 \%$ \\
Caesarean section & 2 & $25 \%$ \\
Aborted & 6 & $75 \%$ \\
Spontaneous & 2 & \\
Induced & 1 & - \\
\hline
\end{tabular}


Table 2: Maternal complications.

\begin{tabular}{|c|c|c|}
\hline $\begin{array}{l}\text { Maternal } \\
\text { complications }\end{array}$ & Number $(\mathrm{n}=\mathbf{1 1})$ & Percentage \\
\hline $\begin{array}{l}\text { Spontaneous } \\
\text { abortions } \\
\text { Induced abortion } \\
\text { Gestational } \\
\text { hypertension } \\
\text { Pre-eclampsia } \\
\text { Eclampsia } \\
\text { HELLP syndrome } \\
\text { SLE Flare } \\
\text { Mild to moderate } \\
\text { Severe } \\
\text { SLE flare in } \\
\text { Antepartum period } \\
\text { Postpartum period } \\
\text { Preterm labour } \\
\text { Post partum } \\
\text { haemorrhage } \\
\text { Oligohydromios } \\
\text { Polyserositis } \\
\text { Death }\end{array}$ & $\begin{array}{l}2 \\
1 \\
2 \\
6 \\
0 \\
1 \\
\\
2 \\
1 \\
\\
2 \\
1 \\
7 \\
4\end{array}$ & $\begin{array}{l}18.18 \% \\
9.09 \% \\
18.18 \% \\
54.54 \% \\
0 \\
9.09 \% \\
18.18 \% \\
9.09 \% \\
\\
18.18 \% \\
9.09 \% \\
87.5 \% \\
50 \%\end{array}$ \\
\hline
\end{tabular}

Table 3: Perinatal outcome.

\begin{tabular}{|l|l|l|}
\hline Outcome & Number $(\mathbf{n = 8})$ & Percentage \\
\hline Born alive & $8 / 8$ & \\
Stillborn & 0 & $100 \%$ \\
Early neonatal & $1 / 8$ & $8.33 \%$ \\
deaths & $5 / 8$ & $12.5 \%$ \\
$\begin{array}{l}\text { Pre term deliveries } \\
\text { Term deliveries }\end{array}$ & $2 / 8$ & $62.5 \%$ \\
$\begin{array}{l}\text { Admission to NICU } \\
\text { Reason for NICU }\end{array}$ & $6 / 8$ & $25 \%$ \\
$\begin{array}{l}\text { admission } \\
\text { Prematurity }\end{array}$ & $5 / 8$ & $75 \%$ \\
$\begin{array}{l}\text { IUGR } \\
\text { Congenital neonatal }\end{array}$ & $1 / 8$ & $62.5 \%$ \\
lupus & 0 & $12.5 \%$ \\
Congenital heart & & \\
block & 0 & \\
\hline
\end{tabular}

\section{DISCUSSION}

The peak incidence of SLE occurs between the ages of 15 and 40 years, with an estimated female-to-male incidence of $9: 1 .^{10}$

In the current study among 11 patients, 63\% (7/11) had remission for $>6$ months before pregnancy, $27 \%$ (3/11)patients had SLE disease activity in the six months before pregnancy and 9\% (1/11) had new onset SLE during pregnancy. Only $25 \%$ pregnancies achieved fullterm deliveries and $62.5 \%$ achieved preterm deliveries. In our study shows new onset SLE occurred during the third trimester of pregnancy, there was a better outcome. A high rate of lupus flare of $27 \%$ was found in the current study. Even among women in remission for more than six months before pregnancy, the rate of lupus flare was not low. Also other complications seen were pre-eclampsia $54.54 \%$, HELLP syndrome in $9.09 \%$, PPH in $50 \%$, polyserositis seen in $9.09 \%$ and one maternal death was seen $(9.09 \%)$. Fortunately, psychiatric and central nervous system manifestations and irreversible renal failure were not found during pregnancy in our study.

\section{Table 4: Therapy of SLE patients during pregnancy} and postpartum.

\begin{tabular}{|c|c|c|}
\hline Causes of jaundice & $\begin{array}{l}\text { Number } \\
(\mathrm{n}=11)\end{array}$ & Percentage \\
\hline $\begin{array}{l}\text { During pregnancy-Oral } \\
\text { prednisone } \\
\text { - iv methylprednisolone } \\
\text {-iv hydrocortisone } \\
\text {-Anti-hypertensive } \\
\text { agents } \\
\text {-Low molecular weight } \\
\text { heparin } \\
\text {-Hydroxychloroquine } \\
\text {-Hemodialysis } \\
\text {-Plasmapheresis } \\
\text { Postpartum } \\
\text { - Hydroxychloroquine } \\
\text {-Prednisone/prednisone } \\
\text {-Cyclophosphamide } \\
\text { - Methotrexate } \\
\text {-Azathioprine }\end{array}$ & $\begin{array}{l}8 \\
11 \\
11 \\
11 \\
0 \\
0 \\
2\end{array}$ & $\begin{array}{l}100 \% \\
- \\
72.72 \% \\
63.63 \% \\
72.72 \% \\
100 \%\end{array}$ \\
\hline
\end{tabular}

Previous studies have shown poor pregnancy outcome in women with SLE. ${ }^{1-5,11}$ The pathogenesis is complex and not completely clarified. Risk factors of pregnant loss in women with SLE include active SLE, new onset SLE during pregnancy, aPLs, hypocomlementemia, antidsDNA antibodies, thrombocytopenia, hypertension and lupus nephritis. ${ }^{1,2,12,16}$ A new study based on 992 SLE patients with 2026 pregnancies suggested that thrombocytopenia, aPL antibodies and anti-SSA antibody are associated with fetal loss in Chinese women. ${ }^{17}$ Although women with SLE have an increased risk of adverse outcomes, patients in remission or stable mild/moderate SLE might have favorable outcomes. ${ }^{1,2,18}$ In the current study, $63.63 \%$ pregnancies of women in remission for more than 6 months had live born infants. Apart from SLE activity, aPLs and anti-Ro/SSA antibody usually are considered highly associated with fetal loss. ${ }^{1,2,15}$ The results of the current study also support that SLE disease activity in the six months before pregnancy is a risk factor of lupus flare and fetal loss. No neonate suffered from heart-blocker however there was $75 \%$ NICU admissions among live births.

Previous studies reported varied widely rate of lupus flare during pregnancy. ${ }^{1,2}$ Lockshin et al reported that pregnancy does not exacerbate SLE. ${ }^{19,20}$ In several prospectively studies, increased rates of lupus flare $(30.8 \%-65 \%)$ during pregnancy were reported..$^{3,12,21-23}$ In some studies, the rates of lupus flare were relative lower, 
still $19.4 \%$ - $28.3 \%$ patients suffered from lupus flare during pregnancy or post-delivery. ${ }^{1,2,24}$

The results of the current study indicated that SLE flare is common in pregnant women with SLE. In our study among 11 patients mild to moderate flare was seen in $18.18 \%$ and severe SLE flare was seen in $9.09 \%$.

Unfortunately, there was one maternal death . In patients with remission of more than six months, the prevalence of lupus flare is significantly lower. Our result supports that planned pregnancy after remission of SLE had better maternal and perinatal outcome.

New onset SLE during pregnancy can be considered as SLE activity and might be associated with worse outcome. ${ }^{25}$ However, the results of the current study indicated that new onset SLE during the third trimester of pregnancy had better outcome.

\section{CONCLUSION}

Advancing technology and better understanding of the maternal-foetal relationship in lupus have improved outcomes in lupus pregnancies over the last decade. The multisystem nature of the disease, the severity of the organ involvement needs to be assessed and a multidisciplinary approach is required for its diagnosis and successful management.

\section{Funding: No funding sources}

Conflict of interest: None declared

Ethical approval: The study was approved by the Institutional Ethics Committee

\section{REFERENCES}

1. Smyth A, Oliveira GH, Lahr BD, Bailey KR, Norby SM, Garovic VD. A systematic review and metaanalysis of pregnancy outcomes in patients with systemic lupus erythematosus and lupus nephritis. Clin J Am Soc Nephrol. 2010;5:2060-8.

2. Stojan G, Alan NB. Flares of systemic lupus erythematosus during pregnancy and the puerperium: Prevention, diagnosis and management. Expert Rev Clin Immunol. 2012;8:439-53.

3. Mintz G, Niz J, Gutierrez G, Alonso A, Karchmer S. Prospective study of pregnancy in systemic lupus erythematosus. Results of a multidisciplinary approach. J Rheumatol. 1986;13:732-9.

4. Georgiou PE, Politi EN, Katsimbri P, Katsimbri P, Sakka V, Drosos AA. Outcome of lupus pregnancy: A controlled study. Rheumatology. 2000;39:1014-9.

5. Soubassi L, Haidopoulos D, Sindos M, Pilalis A, Chaniotis D, Diakomanolis E, et al. Pregnancy outcome in women with pre-existing lupus nephritis. J Obstet Gynaecol. 2004;24:630-4.

6. Lateef A, Petri M. Management of pregnancy in systemic lupus erythematosus. Nat Rev Rheumatol. 2012;8:710-8.
7. Yang MJ, Cheng MH, Lin HY. Onset of systemic lupus erythematosus during pregnancy. J Chin Med Assoc. 2006;69:130-3.

8. Clowse ME, Jamison M, Myers E, James AH. A national study of the complications of lupus in pregnancy. Am J Obstet Gynecol. 2008;199:127-30.

9. Rai R, Cohen H, Dave M, Regan L. Randomised controlled trial of aspirin and aspirin plus heparin in pregnant women with recurrent miscarriage associated with phospholipid antibodies (or antiphospholipid antibodies). BMJ. 1997;314:253-7.

10. Ticconi C, Rotondi F, Veglia M, Pietropolli A, Bernardini S, Ria F, et al. Antinuclear autoantibodies in women with recurrent pregnancy loss. Am J Reprod Immunol. 2010;64:384-92.

11. Petri M, Howard D, Repke J. Frequency of lupus flare in pregnancy. The Hopkins Lupus Pregnancy Center experience. Arthritis Rheum. 1991;34:153845.

12. Hernández CJ, Ros OJ, Paredes F, Casellas M, Castillo F. Clinical predictors of fetal and maternal outcome in systemic lupus erythematosus: A prospective study of 103 pregnancies. Rheumatology (Oxford). 2002;41:643-50.

13. Brucato A, Cimaz R, Caporali R, Ramoni V, Buyon J. Pregnancy outcomes in patients with autoimmune diseases and anti-Ro/SSA antibodies. Clin Rev Allergy Immunol. 2011;40:27-41.

14. Ko HS, Ahn HY, Jang DG. Pregnancy outcomes and appropriate timing of pregnancy in 183 pregnancies in Korean patients with SLE. Int J Med Sci. 2011;8:577-83.

15. Izmirly PM, Saxena A, Kim MY, Wang D, Sahl SK, Llanos C, et al. Maternal and fetal factors associated with mortality and morbidity in a multi-racial/ethnic registry of anti-SSA/Ro-associated cardiac neonatal lupus. Circulation. 2011;124:1927-35.

16. Aggarwal N, Raveendran A, Suri V, Chopra S, Sikka $\mathrm{P}$, Sharma A. Pregnancy outcome in systemic lupus erythematosus: Asia's largest single centre study. Arch Gynecol Obstet. 2011;284:281-5.

17. Tian X, Li M, Ye Z, Zhang X, Liu S. Related factors of fetal loss in Chinese women with systemic lupus erythematosus: data from chinese SLE treatment and research group registry IV. Int $\mathrm{J}$ Rheum Dis. 2014;5:22-7.

18. Buyon JP, Kim MY, Guerra MM, Laskin CA, Petri $\mathrm{M}$, Lockshin MD, et al. Predictors of pregnancy outcomes in patients with lupus: a cohort study. Ann Intern Med. 2015;163:153-63.

19. Lockshin MD. Pregnancy does not cause systemic lupus erythematosus to worsen. Arthritis Rheum. 1989;32:665-70.

20. Lockshin MD, Reinitz E, Druzin ML, Murrman M, Estes D. Case-control prospective study demonstrating absence of lupus exacerbation during or after pregnancy. Am J Med. 1984;77:893-8.

21. Wong KL, Chan FY, Lee CP. Outcome of pregnancy in patients with systemic lupus erythematosus. A 
prospective study. Arch Intern Med. 1991;151:26973.

22. Irastorza G, Lima F, Alves J, Khamashta MA, Simpson J, Hughes GR, Buchanan NM. Increased rate of lupus flare during pregnancy and the puerperium: A prospective study of 78 pregnancies. Br J Rheumatol. 1996;35:133-8.

23. Al Arfaj, Khalil N. Pregnancy outcome in 396 pregnancies in patients with SLE in Saudi Arabia. Lupus. 2010;19:1665-73.

24. Cavallasca JA, Laborde HA, Ruda VH, Nasswetter GG. Maternal and fetal outcomes of 72 pregnancies in Argentine patients with systemic lupus erythematosus (SLE). Clin Rheumatol. 2008;27:416.

25. Zhao CM, Zhao J, Huang Y, Wang Z, Wang H, Zhang H, Xu H, Yang N. New-onset systemic lupus erythematosus during pregnancy. Clin Rheumatol. 2013;32:815-22.

Cite this article as: Leelavathi, Nayana DH, Kondareddy T, Kaytri S. SLE during pregnancy, maternal and perinatal outcome in teritary hospital. Int J Reprod Contracept Obstet Gynecol 2017;6:507-11. 